Short Communication

\title{
Study of Electrodeposited Ni-TiAIN Composite Films
}

\author{
Esmar Budi, Alief Restu, Bagus Ksatriotomo, Iwan Sugihartono, Agus Setyo Budi \\ Department of Physics, Faculty of Science and Mathematics, Universitas Negeri Jakarta, \\ J1. Pemuda No. 10, Jakarta 13220, Indonesia \\ *E-mail: esmarbudi@unj.ac.id \\ doi: $10.20964 / 110402938$
}

Received: 15 October 2015 / Accepted: 4 February 2016 / Published: 1 March 2016

\begin{abstract}
A study results of electrodeposited Ni-TiAlN composite films is reported. The composite film was electrodeposited from electrolyte solution of $0.38 \mathrm{M} \mathrm{Ni} 2 \mathrm{SO} 4.6 \mathrm{H} 2 \mathrm{O}, 0.17 \mathrm{M} \mathrm{NiCl} 2.6 \mathrm{H} 2 \mathrm{O}$ and $0.49 \mathrm{M}$ $\mathrm{H} 3 \mathrm{BO} 3$ adding with various electrodeposition current from $2 \mathrm{~mA}$ to $4 \mathrm{~mA}$ and TiN and AlN powder from $2 \mathrm{gr} / \mathrm{lit}$ to $8 \mathrm{gr} / \mathrm{lit}$. The morphology and compositions were characterized by using SEM/EDS while the crystal structure was characterized by XRD. The results show that the morphology and structure of composite films were influenced by electrodeposition parameters such as electrodeposition current and nitride particle concentration. The evolution of surface morphology and structure was occured as the electrodeposition current and nitride particles concentration were increased. The smoothest and uniform film surface was achieved at high electrodeposition current. However, the agglomeration and initialy spalling film were occured at high nitride particles concentration. Structure analysis of the films revealed the presence of TiN and AlN crystalline in the composite film.
\end{abstract}

Keywords: Electrodeposition, Ni-TiAlN composite film, tungsten carbide, morphology, composition, structure.

\section{$\underline{\text { FULL TEXT }}$}

(C) 2016 The Authors. Published by ESG (www.electrochemsci.org). This article is an open access article distributed under the terms and conditions of the Creative Commons Attribution license (http://creativecommons.org/licenses/by/4.0/). 